\title{
Integrasi Taguchi Loss Function dengan Fuzzy Analytical Hierarchy Process dalam Pemilihan Pemasok
}

\author{
Ahmad S. Indrapriyatna ${ }^{1}$, Yumi Meuthia ${ }^{1}$, Dicky Fatrias $^{1}$, Monalisa Gusti ${ }^{1}$
}

\begin{abstract}
One important issue in the line production is the selection of the company's best supplier. Various criteria should be considered for determining the best supplier. Answering to that challenge, we apply Taguchi loss function-Analytical Hierarchy Process Fuzzy-Linear Programming (Taguchi loss function-Fuzzy AHP) to find out the best supplier. Moreover, we also consider multiple criteria, i.e., goods' completeness, quality, delivery, and quality loss in that analysis. By maximizing the suppliers' performances based on each criterion and aggregated the suppliers' performances based on the overall criteria, we selected the best one. Applying this method for selecting the best pressure gauge's supplier in PT. Coca Cola Bottling Indonesia Central Sumatera (PT. CCBICS), we found out that among three suppliers, the second supplier is the best one.
\end{abstract}

Keywords: Supplier selection, taguchi loss function, AHP, fuzzy linear programming.

\section{Pendahuluan}

Penentuan pemasok terbaik telah menjadi sebuah strategi kunci dalam persaingan dunia manufaktur. Persaingan berdasarkan waktu, kualitas, dan sejenisnya menjadi sesuatu yang sangat penting sebagai tolak ukur dalam pemilihan pemasok. Weber dan Ellram [15] menyatakan kebutuhan akan pemasok yang memiliki kualitas tinggi akan selalu menjadi sebuah isu yang penting dalam dunia manufaktur.

Perusahaan yang semakin berkembang semakin teliti dalam memilih pemasok. Hal ini dapat terwujud dengan memperbanyak kriteria pemilihan pemasok, baik kualitatif maupun kuantitatif (Hwang et al. [4]). Nydick dan Hill [7] menyatakan bahwa kriteria yang bisa digunakan dalam pemasok adalah: harga, pengiriman, kualitas, dan servis. Berdasarkan hal ini maka pemilihan pemasok dilakukan dengan pendekatan kriteria majemuk. Pada dunia nyata, seringkali kemampuan pemasok berdasarkan beberapa kriteria saling berbeda. Sebagai contoh pemasok A menawarkan barang dengan harga relatif murah namun kualitas rendah, lain halnya dengan pe masok B menawarkan barang dengan kualitas yang tinggi namun waktu pengiriman lebih lama. Berdasarkan hal tersebut dapat dilihat setiap pemasok memiliki tingkat pemenuhan kriteria yang berbedabeda satu sama lain dan kriteria yang digunakan mempunyai sifat yang berbeda, yaitu kuantitatif dan kualitatif. Oleh karena itu diperlukan suatu teknik yang dapat mengarahkan pengambilan keputusan

\footnotetext{
1 Fakultas Teknologi Industri, Jurusan Teknik Industri, Universitas Andalas. Kampus Limau Manis, Padang 25163. Email: ahmadsyaf@ft.unand.ac.id
}

Terima 26 September 2011; revisi1 31 Oktober 2011; revisi2 10 November 2011; diterima untuk 21 November dipublikasikan 2011. yang bisa mengikutsertakan perhitungan kualitatif dan kuantitatif untuk menentukan tingkat kepentingan masing-masing kriteria terhadap setiap pembelian.

Vendor Profile Analysis merupakan salah satu pendekatan yang sering digunakan dalam pemilihan pemasok. Kelebihan metode ini dapat mengatasi ketidakpastian yang terdapat dalam pemilihan pemasok. Akan tetapi metode ini tidak dapat mengevaluasi secara kualitatif. Kekurangan dari metode ini dapat diatasi oleh Analytical Hierarchy Process (AHP) yang diperkenalkan oleh Saaty [9] (Nydick dan Hill, [7]). Guller [3] menyatakan AHP sangat bermanfaat bagi manajer dalam memformulasikan kriteria pengambilan keputusan yang diinginkan, memberikan tingkat kepentingan yang berbeda-beda kepada setiap kriteria pengambilan keputusan yang diinginkan, memberikan tingkat kepentingan yang berbeda-beda kepada setiap kriteria, yang kemudian mengevaluasi alternatif kemungkinan yang ada untuk memperoleh keputusan terbaik.

Di sisi lain, banyak nilai dari kriteria dalam pemilihan pemasok dinyatakan dalam bentuk yang tidak presisi, misalkan 'kira-kira lebih dari ...", atau "kira-kira kurang dari ...", atau "suatu nilai diantara ...” dan lain-lain. Kekaburan dalam informasi kritis tersebut tidak dapat ditangkap oleh metode deterministik, sehingga solusi yang didapatkan tidak menjawab tujuan dari pemodelan permasalahan tersebut (Amid dan O'Brien, [1]). Fuzzy Programming mempunyai kemampuan baik untuk pemasalahan multi-objektif maupun kekaburan informasi (vagueness of information). Fuzzy objective dan Fuzzy Constraint yang digunakan dalam optimisasi Fuzzy Programming berfungsi untuk mengakomodasi ke- 
kaburan informasi yang terjadi dalam permasalahan pemilihan pemasok dengan kriteria tidak presisi tersebut (Zimmerman, [16]).

Metode AHP dengan Fuzzy Linear Programming, sering dikombinasikan dalam pengambilan keputusan. Kriteria pada AHP menjadi variabel yang dioptimalkan dalam Fuzzy Linear Programming. Namun, kombinasi dari metode ini belum cukup meyakinkan karena metode ini hanya memaksimasi atau meminimasi variabel untuk pengambilan keputusan tanpa mempertimbangkan nilai loss dari pilihan yang ada. Hal ini dikarenakan minimasi/ maksimasi variabel hanya menentukan jumlah saja. Padahal banyak hal lain selain ketepatan jumlah yang akan mempengaruhi, misalnya kualitas barang dan ketepatan waktu pengiriman.

Taguchi Loss Function adalah metode yang efektif untuk rekayasa kualitas, karena memperhitungkan kesesuaian barang dengan spesifikasi yang telah ditentukan (Kethley et al. [5]). Kerugian terjadi apabila kualitas dari suatu produk keluar dari batas spesifikasi, sehingga tidak dapat diterima. Menurut Kethley et al. [5], Taguchi mengusulkan rentang toleransi yang sempit untuk karakteristik dalam pemilihan pemasok sehingga setiap penyimpangan dari karakteristik nilai target mengakibatkan kerugian dan pengukuran kualitas yang lebih tinggi akan menghasilkan variasi yang minimal dari nilai target. Sebagai contoh, loss adalah nol ketika karakteristik pengukuran sama dengan nilai target. Kerugian dapat diukur dengan menggunakan fungsi kuadrat dan tindakan yang diambil secara sistematis mengurangi variasi dari nilai target.

Kombinasi dari AHP - Programa Linear Fuzzy telah dilakukan oleh Sevkli et al. [12]. Metode ini mengadopsi model programa linear fuzzy kriteria majemuk yang telah dikembangkan oleh Zimmerman [16]. Metode ini diaplikasikan dalam sebuah kasus pemilihan pemasok industri. Pi dan Low [8] mengombinasikan AHP dengan Taguchi Loss Function dalam pemilihan pemasok. Sejauh ini, belum ditemukan penelitian yang menggunakan integrasi AHP - Programa Linear Fuzzy dengan Taguchi Loss Function dalam pemilihan pemasok. Hal ini dirasa perlu karena masalah kekaburan informasi dan kualitas dalam menentukan pemilihan pemasok sering muncul dalam praktek.

PT. Coca Cola Bottling Indonesia Central Sumatera (PT. CCBICS) merupakan perusahaan yang memproduksi minuman berkarbonasi yang terkenal dan laku di pasaran, dengan merek dagang diantaranya: Coca Cola, Sprite, dan Fanta. Pemilihan pemasok yang dilakukan PT. CCBICS adalah salah satu aspek penting yang menjamin kelancaran operasional perusahaan. Pemilihan pemasok yang tidak tepat akan mengakibatkan kegiatan produksi dan operasional terganggu. Bagian purchasing pada PT.
CCBICS melakukan pemilihan pemasok dengan cara menentukan terlebih dahulu pemasok yang menawarkan barang dengan harga paling rendah, jika harga yang ditawarkan pemasok berbeda-beda maka pemasok dengan harga terendah akan dipilih sebagai pemasok komponen tersebut.

Pada penelitian ini dilakukan proses pemilihan pemasok alat pengukur tekanan atau pressure gauge. Pressure gauge merupakan sebuah alat yang digunakan untuk mengukur tekanan larutan dari minuman yang diolah PT. CCBICS. Presure gauge ini sangat dibutuhkan dalam kelangsungan proses produksi PT. CCBICS.

PT. CCBICS melakukan pemilihan pemasok berdasarkan kriteria harga. Namun menurut Sarkis dan Talluri [11], yang dikutip dari Bayazit et al. [2] mengatakan bahwa hubungan buyer-supplier yang hanya didasarkan pada kriteria harga tidak lagi bisa diterapkan. Pentingnya keputusan pemilihan pemasok mengharuskan organisasi memikirkan ulang strategi pengadaan dan evaluasi karena keputusan pengadaan yang tepat sangat tergantung pada pemasok yang tepat. Dengan demikian, evaluasi dan pemilihan pemasok perlu dilakukan dengan mempertimbangkan lebih banyak kriteria. Berdasarkan hal di atas, maka dipandang perlu untuk meningkatkan proses pemilihan pemasok pada PT. CCBICS dengan menggunakan lebih banyak kriteria agar pemasok yang terpilih merupakan pemasok yang terbaik dari berbagai aspek penilaian.

Penelitian ini mengusulkan metode integrasi Fuzzy AHP dan Taguchi Loss Function dalam proses pemilihan pemasok alat ukur tekanan (pressure gauge). Teori fuzzy dipandang cocok untuk diterapkan karena karakteristik masalah pemilihan pemasok cenderung bersifat fuzzy. Hal ini karena sering ditemui kekaburan (vagueness) akibat adanya ketidakpastian dan informasi yang tidak lengkap dari kriteria pemilihan (Amid dan O'Brien, [1]). AHP diterapkan untuk menentukan tingkat kepentingan relatif kriteria pemilihan, dan Taguchi Loss Function digunakan untuk menentukan potensi kerugian yang ditimbukan sebagai konsekuensi atas alokasi barang kepada tiap-tiap pemasok berdasarkan kriteria pemilihan yang telah ditetapkan.

Tujuan dilakukan penelitian ini mengetahui pemasok terbaik untuk PT. CCBICS dengan mengintegrasikan Taguchi Loss Function dengan Fuzzy AHP.

\section{Metode Penelitian}
Notasi
$Z_{i} \quad$ : fungsi tujuan untuk kriteria $i$
$Z_{k}^{\min }$ : nilai $Z_{k}$ minimum
$Z_{k}^{\text {maks }}$ : nilai $Z_{k}$ maksimum 


$\begin{array}{lll}x_{k} & : \text { nilai untuk pemasok ke- } k \\ x_{i j}^{\prime} & : \text { nilai perhitungan bobot untuk kriteria } i \\ & & \text { dibandingkan dengan kriteria } j \\ \mu_{Z k} & : \text { fungsi keanggotaan fuzzy untuk } Z_{k} \\ w_{k} & : \text { bobot kriteria yang didapat dari AHP } \\ W_{j} & : \text { bobot kepentingan ke- } j \\ B_{i} & : \text { bobot lokal kriteria } i \\ B_{k i} & : \text { bobot lokal pemasok } k \text { berdasarkan kriteria } i \\ W S F_{i} & : \text { faktor penjumlah bobot kriteria } i \\ C F_{i} & : \text { faktor konsistensi kriteria } i \\ C F & : \text { rata-rata faktor konsistensi evaluasi } \\ & & \text { kriteria } \\ C I_{i} & : \text { indeks konsistensi evaluasi pemasok } \\ & & \text { berdasarkan kriteria } i \\ C R_{i} & : \text { rasio konsistensi evaluasi pemasok } \\ & & \text { berdasarkan kriteria } i \\ L & : \text { nilai loss } \\ A & : \text { biaya produk cacat } \\ \Delta & : \text { batas toleransi } \\ v^{2} & : \text { mean square deviasi nilai yang dihasilkan } \\ & \quad \text { dari nilai target } \\ m & : \text { banyak pemasok } \\ n & : \text { banyak kriteria } \\ k & : \text { indeks untuk pemasok } \\ i & : \text { indeks untuk kriteria } \\ j & : \text { indeks kepentingan, di sini } j=1 \text { adalah } \\ & \text { kepentingan kriteria dan } j=2 \text { adalah } \\ & \text { kepentingan loss } \\ & \end{array}$

Tahapan-tahapan untuk mengetahui pemasok terbaik untuk PT. CCBICS dengan mengintegrasikan Taguchi Loss Function dengan Fuzzy AHP diuraikan berikut ini. Langkah pertama adalah menentukan kriteria pemilihan pemasok dan alternatif pemasok. Berdasarkan wawancara dengan Kepala dan beberapa staf Bagian Purchasing, diketahui bahwa semua pemasok pressure gauge menawarkan harga yang tidak jauh berbeda. Hal itu menyebabkan kriteria harga yang diterapkan dalam pemilihan pemasok tidak relevan lagi. Diskusi lebih lanjut dilakukan untuk menentukan kriteria yang cocok dipakai dalam pemilihan pemasok ini. Berdasarkan beberapa data historis disepakati bahwa ada 3 (tiga) kriteria dalam pemilihan pemasok yang akan diperhitungkan, yaitu kelengkapan, kualitas, dan pengiriman barang. Kelengkapan barang dipandang dari kesesuaian pemasok memberikan barang yang sesuai dengan jumlah yang dipesan oleh perusahaan. Kualitas dipandang dari kesesuaian pemasok memberikan barang yang sesuai dengan spesifikasi perusahaan. Pengiriman dipandang dari kemampuan pemasok mengirimkan barang tepat waktu sesuai jadwal yang telah disepakati. PT CCBICS mempunyai 3 pamasok untuk pressure gauge ini.

Langkah lanjutan setelah kriteria ditentukan adalah melakukan perbandingan berpasangan (pairwise comparison) terhadap masing-masing kriteria dan subkriteria pemilihan pemasok sehingga nanti- nya diperoleh bobot lokal kriteria. Berdasarkan perbandingan berganda bobot lokal kriteria ini maka dihitung faktor konsistensi evaluasi kriteria yang dilakukan. Evaluasi alternatif pemasok dengan kriteria yang telah ditentukan, akan menghasilkan bobot lokal pemasok. Perhitungan bobot lokal kriteria diperlukan untuk menghitung rasio konsistensi (consistency ratio - CR) terhadap evaluasi yang telah dilakukan. Jika rasio konsistensi lebih kecil atau sama dengan $(\leq)$ 0,1 maka hasil evaluasi pemasok dapat diterima.

Perhitungan nilai loss masing-masing pemasok berdasarkan kriteria yang telah ditentukan kemudian dilakukan. Perhitungan nilai loss masing-masing pemasok terdiri atas 2 metode yaitu The Nominal The Best, dengan toleransi plus/minus tidak sama, untuk kriteria pengiriman dan The Smaller The Better untuk kriteria kelengkapan barang dan krteria kualitas.

Langkah yang dilakukan kemudian adalah menghitung nilai weighted Taguchi loss masing-masing pemasok. Nilai weighted Taguchi loss merupakan jumlah total dari perkalian antara nilai bobot kriteria dengan nilai loss kriteria. Nilai normalisasi dari weighted Taguchi loss didapatkan dari hasil pembagian antara nilai weighed taguchi loss dengan total nilai weighted Taguchi loss tiap-tiap pemasok.

Membuat model pemilihan pemasok berdasarkan kriteria, weighted Taguchi loss, fungsi pembatas, dan pemasok adalah langkah perhitungan lanjutan. Perhitungan untuk pemilihan pemasok berdasarkan kriteria, fungsi pembatas, dan pemasok menggunakan fungsi keanggotaan kurva $\mathrm{S}$ yang dimodifikasi (Vasant, [14]). Adapun fungsi keanggotaan pada kurva S yang dimodifikasi dapat dilihat pada Persamaan (1).

Untuk fuzzy programa linear kriteria majemuk sebanyak $n$, dan banyak pemasok $m$, dengan bobot kriteria untuk masing-masing pemasok $w_{k}$ maka persamaan yang digunakan untuk menentukan fungsi tujuan setiap kriteria diberikan pada persamaan (2) (Zimmerman, [16]).

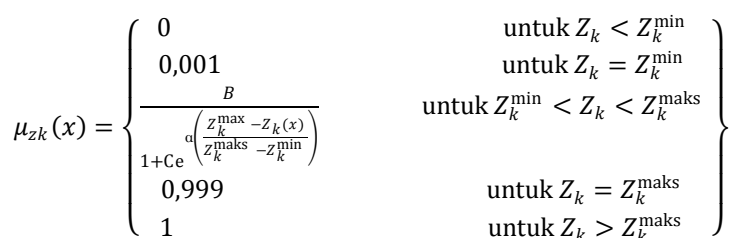

dengan: $B=1 ; \alpha=13,81 ; C=0,001$.

$Z_{i}=\sum_{k=1}^{n} w_{k} x_{k} ;$ untuk setiap $i=1,2, \ldots, m$

Persamaan (2) jika ditambahkan dengan nilai nonnegativitas dari prioritas pemasok $x_{i}$, maka akan menjadi programa linear berikut (Zimmerman, [16]): Fungsi Tujuan: Maksimasi dan minimasi 
$Z_{i}=\sum_{k=1}^{n} w_{k} x_{k} ;$ untuk setiap $i=1,2, \ldots, m$

Batasan:

$\sum_{k=1}^{n} x_{k}=1$

$w_{k} \geq 0$

$x_{k} \geq 0, \quad k=1,2,3, \ldots, n$

Setelah itu ditentukan batas bawah dan batas atas dari fungsi tujuan yang akan digunakan untuk menyelesaikan kasus pemilihan pemasok kriteria majemuk menjadi kriteria tunggal dengan bantuan software Lindo 6.0. Perhitungan berikutnya adalah menentukan batas bawah (minimasi) dan batas atas (maksimasi) dari fungsi tujuan (3) yang akan digunakan untuk menentukan fungsi keanggotaan masing-masing fungsi tujuan tersebut.

Langkah berikutnya adalah membuat model Taguchi loss function-fuzzy AHP dengan satu fungsi tujuan. Fungsi loss untuk kriteria pengiriman adalah (Taguchi et al., [13]):

$L=\frac{1}{n}\left[\frac{A_{1}}{\Delta_{1}^{2}} \sum(y-m)^{2}+\frac{A_{2}}{\Delta_{2}^{2}} \sum(y-m)^{2}\right]$

Sedangkan fungsi loss untuk kriteria kelengkapan barang dan kriteria kualitas adalah (Taguchi et al., [13]):

$L=\frac{A}{\Delta^{2}} v^{2}$

Perhitungan terakhir adalah mencari solusi optimal untuk memperoleh skor masing-masing pemasok. Dalam penelitian ini perhitugan pencarian solusi optimal diperoleh dengan menggunakan bantuan Solver Microsoft Excel. Berdasarkan solusi optimal ini maka dapat ditentukan pemasok terbaik.

\section{Hasil dan Pembahasan}

Hasil pengumpulan data, pengolahan data, dan pembahasan disajikan berikut ini.

\section{Pengumpulan Data}

Berdasarkan catatan bulan Juli - Oktober pada Bagian Purchasing maka didapatkan data sebagai berikut. Tabel 1 menunjukkan data kekurangan barang dan Tabel 2 memperlihatkan data banyak produk cacat yang diterima dari pemasok. Tabel 3 menunjukkan data performansi pemasok berdasarkan kriteria pengiriman. Jika pemasok mengirim tepat waktu maka diberi nilai nol, jika mengirimkan lebih cepat dari waktu yang disepakati maka ditulis dengan angka positif, dan jika lebih lambat dari waktu yang disepakati ditulis dengan angka negatif. Walaupun diberi angka positif, tetap pemasok akan dikenakan biaya penalty. Di sini dipakai satuan minggu sebagai acuan.
Tabel 1. Data kekurangan barang

\begin{tabular}{lccc}
\hline \multirow{2}{*}{ Bulan } & \multicolumn{3}{c}{ Pemasok } \\
\cline { 2 - 4 } & Pemasok 1 & Pemasok 2 & Pemasok 3 \\
\hline Juli & 1 & 0 & 0 \\
Agustus & 0 & 0 & 0 \\
September & 0 & 0 & 1 \\
Oktober & 1 & 0 & 0 \\
\hline
\end{tabular}

Tabel 2. Data banyak produk cacat yang diterima

\begin{tabular}{lccc}
\hline \multirow{2}{*}{ Bulan } & \multicolumn{3}{c}{ Pemasok } \\
\cline { 2 - 4 } & Pemasok 1 & Pemasok 2 & Pemasok 3 \\
\hline Juli & 0 & 0 & 0 \\
Agustus & 1 & 0 & 1 \\
September & 1 & 0 & 0 \\
Oktober & 0 & 1 & 0 \\
\hline
\end{tabular}

Tabel 3. Data performansi pengiriman

\begin{tabular}{lccc}
\hline \multirow{2}{*}{ Bulan } & \multicolumn{3}{c}{ Pemasok } \\
\cline { 2 - 4 } & Pemasok 1 & Pemasok 2 & Pemasok 3 \\
\hline Juli & 0 & 1 & 0 \\
Agustus & 0 & 0 & 0 \\
September & 0 & 0 & -1 \\
Oktober & 0 & 0 & 1 \\
\hline
\end{tabular}

Tabel 4. Batas spesifikasi kriteria

\begin{tabular}{lcl}
\hline \multicolumn{1}{c}{ Kriteria } & \multicolumn{1}{c}{ Target } & \multicolumn{1}{c}{ Toleransi } \\
\hline $\begin{array}{l}\text { Kelengkapan } \\
\text { Barang }\end{array}$ & - sesuai kriteria & Maks 3 \\
Kualitas & $\begin{array}{c}\text { 0-tidak ada yang } \\
\text { cacat }\end{array}$ & Maks 3 \\
Pengiriman & 0 - sesuai hari H & $\begin{array}{l}\text { Lebih cepat 2 unit waktu, } \\
\text { paling lambat 4 unit } \\
\end{array}$ \\
& & waktu \\
\hline
\end{tabular}

Tabel 5. Penalti untuk pelanggaran

\begin{tabular}{lc}
\hline \multicolumn{1}{c}{ Kriteria } & Penalti \\
\hline Kelengkapan Barang & $\mathrm{Rp} 1.250 .000,00$ \\
Kualitas & $\mathrm{Rp} 1.250 .000,00$ \\
Pengiriman & $\mathrm{Rp} 1.850 .000,00$ \\
\hline
\end{tabular}

Tabel 6. Rekapitulasi nilai loss pemasok untuk setiap kriteria

\begin{tabular}{llll}
\hline \multirow{2}{*}{ Kriteria } & \multicolumn{3}{c}{ Pemasok } \\
\cline { 2 - 4 } & \multicolumn{1}{c}{ Pemasok 1 } & Pemasok 2 & Pemasok 3 \\
\hline Kelengkapan & $\operatorname{Rp~69.444,44~}$ & $\operatorname{Rp~0,00}$ & Rp 0,00 \\
Barang & & & \\
Kualitas & $\operatorname{Rp~69.444,44~}$ & $\operatorname{Rp~34.722,22~}$ & $\operatorname{Rp~34.722,22~}$ \\
Pengiriman & $\operatorname{Rp~0,00~}$ & $\operatorname{Rp~34.722,22~}$ & $\operatorname{Rp~34.722,22~}$ \\
\hline
\end{tabular}

Tabel 7. Taguchi loss masing-masing pemasok

\begin{tabular}{ccc}
\hline Pemasok & $\begin{array}{c}\text { Weighted Taguchi } \\
\text { Loss }\end{array}$ & $\begin{array}{c}\text { Normalized Weighted } \\
\text { Taguchi Loss }\end{array}$ \\
\hline Pemasok 1 & Rp 63.659,17 & 0,47 \\
Pemasok 2 & Rp 27.529,86 & 0,20 \\
Pemasok 3 & Rp 43.870,18 & 0,33 \\
\hline
\end{tabular}

Batas spesifikasi kriteria serta penalti yang diberikan kepada pemasok apabila terjadi pelanggaran terhadap peraturan yang ditetapkan dapat dilihat pada Tabel 4 dan 5. Batas-batas spesifikasi dan penalti pelanggaran ditentukan oleh perusahaan 
sesuai dengan kontrak yang disepakati bersama pemasok berdasarkan keterangan dari Kepala Bagian Purchasing.

\section{Pengolahan Data}

Perhitungan bobot lokal kriteria diawali dengan perbandingan berpasangan kriteria pemilihan pemasok, yang menghasilkan total nilai secara berurutan untuk Kelengkapan Barang, Kualitas, dan Pengiriman adalah 6,33; 1,34; dan 11,00. Bobot lokal kriteria secara berurutan untuk Kelengkapan Barang, Kualitas, dan Pengiriman adalah 0,19; 0,73; dan 0,08.

Perhitungan rasio konsistensi menghasilkan $\mathrm{CR}=$ 0,06 . Karena nilai $\mathrm{CR} \leq 0,1$ maka hasil evaluasi dapat diterima.

Proses yang sama dilakukan untuk melihat bobot lokal pemasok, yang menghasilkan nilai CR untuk masingmasing kriteria secara berurutan untuk Kelengkapan Barang, Kualitas, dan Pengiriman adalah 0,01; 0,05; dan 0,03. Diperoleh nilai $\mathrm{CR} \leq 0,1$ maka hasil evaluasi dapat diterima.

Rekapitulasi nilai loss pemasok untuk setiap kriteria dapat dilihat pada Tabel 6. Hasil perhitungan dari weighted Taguchi loss serta normalisasi untuk masing-masing pemasok dapat dilihat pada Tabel 7. Nilai dari normalisasi weighted Taguchi loss digunakan untuk menentukan skor masing-masing pemasok.

Fungsi keanggotaan pada kurva S untuk Persamaan (1) direpresentasikan oleh Gambar 1.

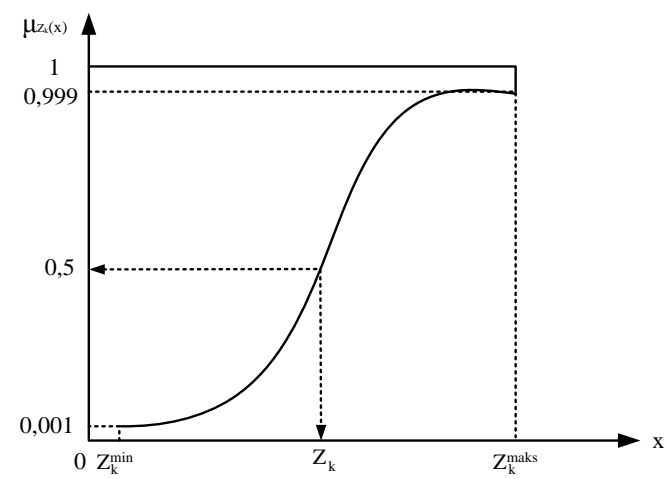

Gambar 1. Representasi Fungsi Keanggotaan Kurva S

Tabel 8. Rekapitulasi $Z_{k}^{\min }$ dan $Z_{k}^{\max }$ masing-masing fungsi tujuan

\begin{tabular}{clcc}
\hline Notasi & \multicolumn{1}{c}{ Kriteria } & $Z_{k}^{\min }$ & $Z_{k}^{\max }$ \\
\hline$Z_{1}$ & Kelengkapan & 0,16 & 0,54 \\
& Barang & & \\
$Z_{2}$ & Kualitas & 0,14 & 0,52 \\
$Z_{3}$ & Pengiriman & 0,11 & 0,63 \\
$Z_{4}$ & Quality loss & 0,20 & 0,47 \\
\hline
\end{tabular}

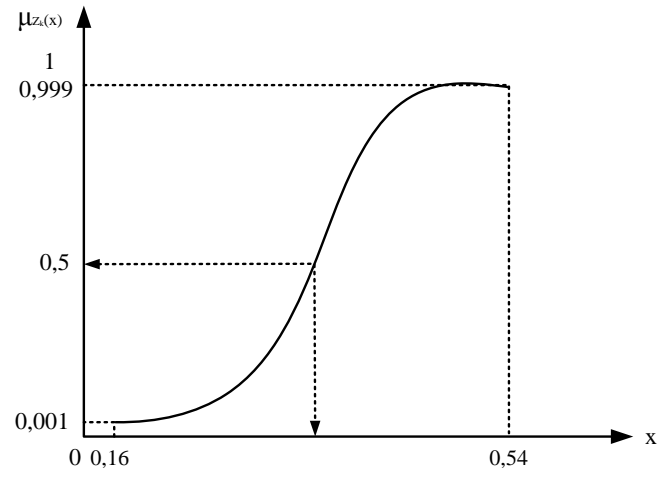

Gambar 2. Representasi fungsi kengggotaan $\mathrm{Z}_{1}$

Berdasarkan Model programa linear fuzzy kriteria majemuk untuk kasus pemilihan pemasok pressure gauge sebagai berikut:

$\operatorname{Max} Z_{1}=0,16 x_{1}+0,54 x_{2}+0,30 x_{3}$
$\operatorname{Max} Z_{2}=0,14 x_{1}+0,52 x_{2}+0,34 x_{3}$
$\operatorname{Max} Z_{3}=0,63 x_{1}+0,26 x_{2}+0,11 x_{3}$
$\operatorname{Max} Z_{4}=0,47 x_{1}+0,20 x_{2}+0,33 x_{3}$

Batasan:

$x_{1}+x_{2}+x_{3}=1$

$x_{1}, x_{2}, x_{3} \geq 0$

Pencarian nilai batas atas dan batas bawah fungsi tujuan dilakukan maksimasi dan minimasi fungsi tujuan dengan menggunakan software Lindo 6.0, yang dapat dilihat pada Tabel 8.

Fungsi keanggotaan masing-masing fungsi tujuan memaksimasi prioritas pemasok dan meminimasi nilai loss berdasarkan kriteria. Fungsi keanggotaan tersebut dijabarkan sebagai berikut:

Fungsi keanggotaan $Z_{1}$ adalah:

$\mu_{z 1}(x)=\left\{\begin{array}{lr}0 & \text { untuk } Z_{1}(x)<0,16 \\ 0,001 & \text { untuk } Z_{1}(x)=0,16 \\ \frac{\mathrm{B}}{1+\mathrm{C} \mathrm{e}^{\mathrm{a}\left(\frac{54-Z_{1}(x)}{0,54-0,16}\right)}} & \text { untuk } 0,16<Z_{1}(x)<0,54 \\ 0,999 & \operatorname{untuk} Z_{1}(x)=0,54 \\ 1 & \operatorname{untuk} Z_{1}(x)>0,54\end{array}\right\}$

Fungsi keanggotaan masing-masing fungsi tujuan memaksimasi prioritas pemasok dan meminimasi nilai loss berdasarkan kriteria. Nilai fungsi keanggotaan menunjukkan tingkat penerimaan dari masing-masing nilai $Z_{\text {i. }}$ Fungsi keanggotaan $Z_{1}$ direpresentasikan pada Gambar 2. Selanjutnya untuk representasi fungsi keanggotaan $Z_{2}, Z_{3}$, dan $Z_{4}$ dilakukan dengan cara yang sama.

Fungsi keanggotaan $Z_{2}$ adalah:

$\mu_{z 2}(x)=\left\{\begin{array}{l}0,001 \\ \frac{\mathrm{B}}{1+\mathrm{Ce} \mathrm{a}^{\mathrm{a}\left(\frac{0,52-Z_{2}(x)}{0,52-0,14}\right)}} \\ 0,999 \\ 1\end{array}\right.$

$$
\left.\begin{array}{r}
\text { untuk } Z_{2}(x)<0,14 \\
\text { untuk } Z_{2}(x)=0,14 \\
\text { untuk } 0,14<Z_{2}(x)<0,52 \\
\operatorname{untuk} Z_{2}(x)=0,52 \\
\text { untuk } Z_{2}(x)>0,52
\end{array}\right\}
$$


Fungsi keanggotaan $Z_{3}$ adalah:

$$
\mu_{z 3}(x)=\left\{\begin{array}{lr}
0 & \text { untuk } Z_{3}(x)<0,11 \\
0,001 & \text { untuk } Z_{3}(x)=0,11 \\
\frac{\mathrm{B}}{1+\mathrm{Ce}\left(\frac{0,63-Z_{3}(x)}{0,63-0,11}\right)} & \text { untuk } 0,11<Z_{3}(x)<0,63 \\
0,999 & \text { untuk } Z_{3}(x)=0,63 \\
1 & \text { untuk } Z_{3}(x)>0,63
\end{array}\right\}(17)
$$

Fungsi keanggotaan $Z_{4}$ adalah:

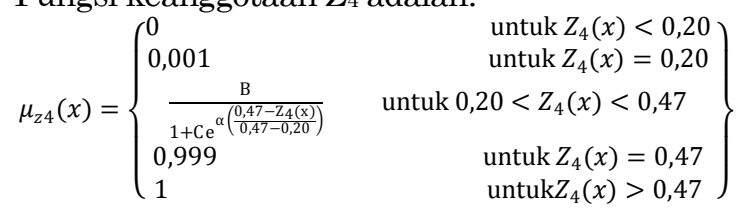

Setelah fungsi keanggotaaan setiap fungsi tujuan diperoleh maka dapat dirancang model Taguchi loss function-Fuzzy AHP sebagai berikut:

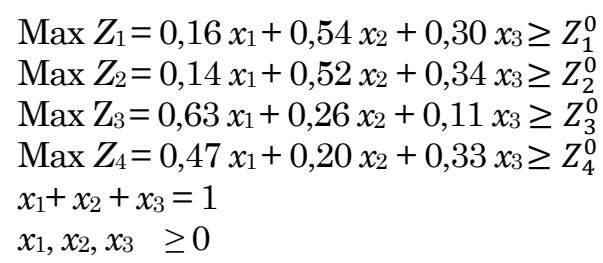

Di sini $Z_{\mathrm{k}}^{0}$ adalah nilai yang ingin dicapai oleh pengambil keputusan, yaitu $Z_{k}^{\text {max }}$ untuk $\mathrm{k}=1,2$ dan $Z_{k}^{\min }$ untuk k=3,4.

Model Taguchi-FuzzyAHP dengan fungsi tujuan tunggal

$$
\operatorname{Max} w_{1}\left(0,19 \lambda_{1}+0,72 \lambda_{2}+0,08 \lambda_{3}\right)+w_{2}\left(\lambda_{4}\right)
$$

Batasan:

$$
\lambda_{1} \leq \frac{\mathrm{B}}{1+\mathrm{Ce}\left(\frac{\mathrm{z}_{\mathrm{k}}^{\max }-\mathrm{z}_{\mathrm{k}}(\mathrm{x})}{\mathrm{z}_{\mathrm{k}}^{\mathrm{maks}}-\mathrm{z}_{\mathrm{k}}^{\min }}\right)}
$$

Di sini $w_{\mathrm{j}}$ ditentukan berdasarkan hasil diskusi antara peneliti dengan kepala bagian purchasing, yaitu $w_{1}=0,7$ dan $w_{2}=0,3$. Nilai $\lambda_{\mathrm{k}}$ merupakan minimasi dari nilai fungsi tujuan $\mu_{\mathrm{zk}}(\mathrm{x})$ sehingga nilai $\lambda_{\mathrm{k}}$ harus lebih kecil atau sama dengan $\mu_{\mathrm{zk}}(\mathrm{x})$, nilai $\lambda_{\mathrm{k}}$ berada dalam rentang 0 sampai 1 , sebagaimana halnya dengan $\mu_{\mathrm{zk}}(\mathrm{x})$.

Nilai batas atas dan batas bawah masing-masing kriteria dimasukkan dalam persamaan di atas. Sehingga menjadi persamaan berikut:

$$
\operatorname{Max} 0,13 \lambda_{1}+0,50 \lambda_{2}+0,06 \lambda_{3}+0,30 \lambda_{4}
$$

Batasan:

$\lambda_{1}+0,001 \lambda_{1} \mathrm{e}^{\left(19,84-6,03 \mathrm{x}_{1}-19,84 \mathrm{x}_{2}-10,94 \mathrm{x}_{3}\right)} \leq 1$

$\lambda_{2}+0,001 \lambda_{2} \mathrm{e}^{\left(18,91-5,10 \mathrm{x}_{1}-18,91 \mathrm{x}_{2}-12,26 \mathrm{x}_{3}\right)} \leq 1$

$\lambda_{3}+0,001 \lambda_{3} \mathrm{e}^{\left(16,82-16,82 \mathrm{x}_{1}-6,92 \mathrm{x}_{2}-2,82 \mathrm{x}_{3}\right)} \leq 1$

$\lambda_{4}+0,001 \lambda_{4} \mathrm{e}^{\left(24,11-24,04 \mathrm{x}_{1}-10,23 \mathrm{x}_{2}-16,88 \mathrm{x}_{3}\right)} \leq 1$

$x_{1}+x_{2}+x_{3}=1$

$x_{1}, x_{2}, x_{3} \geq 0$

$0 \leq \lambda_{1}, \lambda_{2}, \lambda_{3}, \lambda_{4} \leq 1$
Setelah model Taguchi loss function-fuzzy AHP dirancang, selanjutnya dengan menggunakan Solver Microsoft excel didapatkan nilai $x_{1}=0, x_{2}=1$ dan $x_{3}=0$. $x_{2}$ menunjukkan nilai pemasok 2 , maka pemasok yang terpilih adalah pemasok 2 .

Masing-masing nilai $x_{\text {i }}$ tersebut jika disubtitusikan ke fungsi tujuan Persamaan (9)-(12) diperoleh hasil berikut: $Z_{1}=0,54 ; Z_{2}=0,52 ; Z_{3}=0,26 ; Z_{4}=0,20$

Nilai $Z_{i}$ tersebut menunjukkan prioritas masingmasing kriteria pemilihan pemasok. Nilai fungsi keanggotaan fungsi tujuan $\mu_{z_{i}}(x)$ masing-masing fungsi tujuan diperoleh dari nilai-nilai $\lambda_{i}$, berikut adalah nilai-nilai tersebut:

$\mu_{z_{1}}(x)=\lambda_{1}=0,999 ; \mu_{z_{2}}(x)=\lambda_{2}=0,999$

$\mu_{z_{3}}(x)=\lambda_{3}=0,999 ; \mu_{z_{4}}(x)=\lambda_{4}=0,999$

Nilai fungsi keanggotaan menunjukkan tingkat penerimaan dari masing-masing nilai $Z_{i}$. Dari nilainilai $\mu_{z_{i}}(x)$ di atas dapat dilihat bahwa prioritas kriteria masing-masing pemasok berada pada tingkat maksimumnya karena nilai $Z$ yang dihasilkan mencapai 0,99.

\section{Simpulan}

Penelitian ini telah berhasil mengintegrasikan Taguchi Loss Function dengan Fuzzy AHP untuk memilih pemasok terbaik dengan memperhatikan beberapa kriteria. Model yang dihasilkan telah dicobakan pada PT. CCBICS untuk memilih pemasok pressure gauge, menggunakan kriteria kelengkapan, kualitas, dan pengiriman. Berdasarkan hasil pengolahan data dan analisis dapat ditarik kesimpulan bahwa dengan menggunakan integrasi Taguchi loss function dengan Fuzzy-AHP pemasok pressure gauge yang terpilih untuk PT. CCBICS adalah pemasok 2 .

Penelitian ini adalah awal dari serangkaian penelitian yang akan dilakukan. Penelitian lanjutan adalah mengintegrasikan Taguchi Loss Function dengan AHP - Fuzzy Multiobjective Integer Programming. Selain itu, akan dilakukan penelitian dengan menambahkan beberapa kriteria lain, antara lain kriteria faktor benefit dan kriteria lingkungan dalam proses pemilihan pemasok.

\section{Daftar Pustaka}

1. Amid, A., Ghodsypour, S. H., and O'Brien, C., Fuzzy Multiobjective Linear Model for Supplier Selection in a Supply Chain, International Journal Production Economics, 104, 2006, pp. 394-407. 
2. Bayazit, O., Birsen, K., and Ayhan, Y., A Purchasing Decision: Selecting a Supplier for a Construction Company, Journal System Science System Engineering (Springer -Verlag), 15(2), 2006, pp. 217-231.

3. Güller, M. E., Incorporating Multi-Criteria Considerations into Supplier Selection Problem Using Analytical Hierarchy Process: A Case Study, Journal of Yasar University, 3(12), 2008, pp. 1787-1810.

4. Hwang, H. S., Moon, C., Chuang, C. L., and Chuang, M. J., Supplier Selection and Planning Model Using AHP, International Journal of the Information Systems for Logistics and Management (IJISLM), 1(1), 2005, pp. 47-53.

5. Kethley, B., Waller, B., and Festervand, T., Improving Customer Service in The Real Estate Industry: A Property Selection Model Using Taguchi Loss Functions, Total Quality Management, 13(6), 2002, pp. 739-748.

6. Muralidharan C., Anantharaman N., and Deshmukh S. G., A Multi-Criteria Group Decision Making Model for Supplier Rating, Journal of Supply Chain Management, 38(4), 2002, pp. 22- 33.

7. Nydick R., and Hill R. P., Using the Analytic Hierarchy Process to Structure the Supplier Selection Procedure, International Journal of Purchasing and Materials Management, 28(2), 1992, pp. 31-36.

8. Pi, W. N., and Low, C., Supplier Evaluation and Selection Using Taguchi Loss Functions, The International Journal of Advanced Manufacturing Technology, 26, 2005, pp. 155-160.
9. Saaty, T. L., Fundamentals of Decision Making and Priority Theory, RWS Publications, Pittsburgh, 1994.

10. Sadeghian, H. R., and Karami, E., Supplier Evaluation using Loss Function and AHP, Proceedings of the 2010 International Conference on Industrial Engineering and Operations Management, Dhaka, Bangladesh, January 9-10, 2010.

11. Sarkis, J., and Talluri, S., A Model for Strategic Supplier Selection, Journal of Supply Chain Management, 38(1), 2002, pp. 18-29.

12. Sevkli, M., Koh, S. C., Lenny, Zaim, S., Demirbag, M., and Tatoglu, E., Hybrid Analytical Hierarchy Process Model for Supplier Selection, Journal of Industrial Management and Data Systems, 108(1), 2008, pp. 122-142

13. Taguchi, G., Elsayed A. E., and Thomas C. S., Quality Engineering In Production System, Mc-Graw Hill Book Company, 1989.

14. Vasant, P. M., Decision Making using Modified SCurve Membership Function in Fuzzy Linear Programming Problem, Journal of Industrial Management and Data Systems, 2, 2004, pp. 1-16.

15. Weber, C. A., and Ellram, L. M., Supplier Selection using Multi-objective Programming: A Decision Support System Approach, International Journal of Physical Distribution and Logistics Management, 23(2), 1993, pp. 3-15.

16. Zimmermann, H. J., Fuzzy Programming and Linear Programming with Several Objective Functions, Journal of Fuzzy Sets and Systems, 1, 1978, pp. 45-55. 